\title{
Examining How Students' and Lecturers' Perceptions Impact on the Delivery of Clothing and Textiles in Universities
}

\author{
Verity Muzenda \\ School of Further and Continuing Education, University Of Fort Hare, South Africa \\ Email: muzendaverity@yahoo.co.za \\ Ntombozuko Duku \\ School of General and Continuing Education \\ University of Fort Hare, South Africa
}

Doi:10.5901/mjss.2014.v5n23p353

\begin{abstract}
Numerous factors have been seen to have an influence on the delivery of Clothing and Textiles in universities. Among these factors, lecturers' and students' attitudes have been viewed to be the most exceptional factor. Sixty respondents made up the study. The study made use of interviews, questionnaires, focus groups, document analysis and observations as data collection instruments. The Concurrent triangulation design was used. SPSS Statistical package was used for the analysis of quantitative data and themes were used for qualitative data. Findings of the study revealed that lectures' attitudes towards the subject had a bearing on how they delivered the subject and consequently impacted on how students performed in the subject. Furthermore, the way students perceived Clothing and Textiles had a bearing on the way they learn and performed. The study concluded that perceptions of both lecturers and students had both positive and negative influence on the teaching and learning of Clothing and Textiles. The following recommendations were made; Teacher training should include the use of modern machinery and equipment so as to equip lecturers with the skills needed in the delivery of Clothing and Textiles, Clothing and Textiles should be given the same respect like any other subject in the universities and lecturers need to switch from the old traditional teaching methods which are lecturer centred to more modern student learning methods which allow for active learning and increased student participation.
\end{abstract}

Keywords: Perceptions, delivery, Technical and Vocational Education, Clothing and textiles, Curriculum

\section{Introduction}

Determinants of students' academic performance have received significant attention in the education literature. Student performance is generally viewed as product of socio-economic, psychological and environmental factors. The factors are expected to vary from one country to another and from place to place. A myriad of factors have been seen to have an impact on student's performance. Among these, Schneider, Gruman, and Coutts (2012) have found lecturer and student attitudes to be the most outstanding factor. Lecturers' attitudes can both enhance students' academic achievement or can be detrimental to students' achievement as well. Hence, the attempt was made in this study to look at perceptions of lecturers and students as a factor that affects students' performance in Clothing and Textiles (CT) in universities. The attitude and motivation of vocational lecturers have a significant role in improving the image of Technical Vocational Education (TVE) in universities, performance of vocational graduates as well as their willingness to take up TVE at this high level. The attitudes of lecturers also help to shape students' job aspirations. When a lecturer has a positive attitude, he or she will trust that all students will be successful; there are no losers amongst the students (Flores \& Day, 2006). A teacher's positive attitude is a catalyst as it sparks extraordinary results, cause a chain reaction of positive thoughts, events and outcomes.

Key to the success of a vocational programme is lecturers' attitude. Lecturers frequently use practical work as a form of punishment, while they lavish praise on those who do well in their academic courses (Al-Ali, 2005). This may result in lower motivation, less learning and lower probabilities that students will enter the occupations for which they have been. A desired educational outcome may not occur due to the attitude one may be bearing (Schneider, Gruman \& Coutts, 2012). Attitudes play a major role in the success or failure of the delivery of any curriculum in universities. If people involved in the delivery of a particular programme have a negative attitude, it is most likely that the programme will 
not succeed. Rex and Singh (2003) reiterate that negative attitudes of lecturers and students in TVE are the major barrier to the successful delivery of the Clothing and Textiles curriculum.

Lecturers' attitudes have a great influence on what students learn and as such students' perceptions are a reflection of those attitudes held by their lecturers. However, it is worth noting that the word "attitude" often has a negative undertone. Every lecturer or student has an attitude, so it is best to identify the type of attitude that is a healthy attitude, a positive attitude, negative or an agreeable attitude. This attitude focuses on the ability of the lecturer to accommodate students in the learning environment. Research has established that students and lecturers account for each other's' attitudes, thus there is a positive correlation between the attitude lecturers display in any learning situation and that of students (Skinner \& Belmont, 1993). It has been observed that when lecturers do not show maximum commitment when teaching students, there is a high possibility that students will retaliate by having unbecoming behaviour as a way of showing their displeasure on the lecturer's attitude (Demanet \& Van Houtte, 2012; Van Houtte \& Stevens, 2008). Lecturers contribute to their profession through their actions and utterances and these affect those who hear it. According to Cawelti (2004), those lecturers who have high regard for their profession get the same from their students.

Lecturers' attitudes have been seen to have an impact on the climate of any Institution of Higher Learning. Some lecturers display a friendly and accommodative atmosphere and others are not friendly and unaccommodative as well (Hoy, 2003). An accommodative and friendly approach enhances the institutional climate and the learning environment for students whereas an unfriendly and unaccommodative environment impedes students' learning. There is need for a lecturer to exude positive attitude in a learning environment for it is an asset in life. A positive attitude can help one to cope with the day to day stressors in an amicable way without impacting negatively on the students. It is also important to bear in mind that in teaching and learning, everything is not static, there are bound to be changes or disruptions to the day to day activities. This can be as a result of important workshops, conferences or meetings. As a result, a positive attitude is important not only for the lecturer's stress level but also for the students who expect the lecturer to be in charge and take control of any situation that may arise.

Renowned educational researchers from USA, France, Belgium and UK avow that lecturers' attitudes have a significant impact on students' educational achievement (Van Houtte \& Van Maele, 2012). The lecturer resembles the content and the institution. As a result, how a lecturer presents himself or herself is of uttermost importance since it has a bearing on how the students, other lecturers, policy makers and the community perceive the institution (Thornton, Peltier \& Hill, 2005). From the same source, educationists believe that the way a lecturer teaches impacts on the students' preference to a particular subject. A lecturer who is highly enthusiastic about his or her subject area may transfer those feelings to the students. Personality is one of the most fundamental characteristics of a competent lecturer which is not easy to change (Thornton, et al, 2005). As result, one's personality has a bearing on how one delivers a learning programme. As students interact with lecturers on a daily basis, it is likely that lecturers' attitudes also shape other aspects of their lives (Hallinan, 2008). Lecturers' attitudes towards a learning experience can leave a mark on their students' lives. School experiences mold, shape, and, can influence how students view themselves inside and outside of the learning environment. These memories can linger in a students' mind for a long time, even after graduation and this can impact on the decisions they will make in a life time. Positive attitudes and actions employed by lecturers in any learning environment eventually can make a positive difference on the lives of their students.

Recent studies by Gwaradzimba and Shumba (2010) and Makochekanwa and Kwaramba (2010) have shown that the successful delivery of an educational curriculum depends largely on the attitudes of educators who eventually determine how they implement the curriculum in the classroom. Lecturers' attitudes are a major enabling or disabling factor in the delivery of any curriculum (Bullock, 2004). The attitude and motivation of TVE lecturers have a significant role in improving the performance of TVE graduates as well as their willingness to learn. Factors related to motivating lecturers in developing their own programmes include caring for students, attention to professional growth and a desire to keep programmes up-to-date with changing technology (Al-Ali, 2005). A competent lecturer should be able to give students the freedom to learn through exploration and experimentation for this enables both lecturers and students to contribute to the learning environment for a relationship of closeness and acceptance to develop (First Results from TALIS, OECD 2009). In the same vein, Kersaint, Horton, Stohl, and Garofalo (2003) reiterate that lecturers who have positive attitudes towards teaching are comfortable with exploring new methods of making learning easy, for example the use of Computer-aided learning or technology in CT when making patterns. When lecturers are more comfortable with using computer aided learning, they are therefore confident enough to incorporate it into their day to day lectures. Woodrow (2002) stresses that any successful transformation in educational practice requires the development of positive user-attitude towards the new curriculum or technology

TVE lecturers appear as an anomalous group, with an ambivalent status and an unclear identity yet they occupy the most important place in modern society for they are the link between the world of work, and the educational system 
(Oketch, 2007). The lecturers are often not respected or given recognition. They are believed not to possess adequate "formal" qualifications or a "proper" academic background (Kanyongo, 2005). Gumbo (2006) asserts that despite all types of attempts to change students' attitudes that TVE would enable them equally to achieve their goals and improving their position in the same way as academic subjects, it has remained a dream for institutions to deliver massive changes in attitude and aspiration in the absence of any parallel initiatives in the larger economic environment (Kanyongo, 2005). However, this perpetuates the low status students place on TVE. Students perceive TVE as a course for low achievers and as a result, students shun TVE in universities (Mumbengegwi, 2008). Smerdon (2002) found that students in vocational tracks had negative attitudes towards their programme unlike those in academic track. It has been shown that technical or vocational courses are less demanding than academic ones (Van Houtte, 2006a). Practically-oriented tracks, course content is approached in a manner in which emphasis is more on skill acquisition unlike in academically oriented courses in which more emphasis is placed on concepts (Schofield, 2006). As a result of this discrepancy, both lecturers and students have a negative attitude towards practically oriented courses. Smerdon (2002) maintains that lecturers have some conceptions about their job, as a result when they find themselves teaching students in a track which is looked down upon, they find it difficult to adjust. Consequently many lecturers are demotivated and lack confidence in the students they teach and this perpetuates the stereotype that practically-oriented students are academically weak (Van Houtte, 2006b).

The Colonial era has left a legacy which portrays TVE as a career path for the less academically endowed (Johanson \& Adams, 2004). For many parents in African countries, TVE carries an aura of being too non-academic (Cloete, Needham, Net, Papier, Shepard \& Stumpf, 2009). This perception has been driven by the low academic requirements for admission into TVE programmes (Johanson \& Adams, 2004). These deeply embedded attitudes are difficult to change. Therefore, holding lower expectations on TVE for some students can perpetuate lower academic performance and inhibit students' success. Thus, the duration of training of TVE programmes, combined with the lower formal qualifications typically required by Ministries of Higher Education, (Baker, Fabrega, Galindo, \& Mishook, 2004) as compared to other academic subject perpetuates the low status students place on TVE. Students do not take TVE seriously and they label such students as low achievers and as a result, students shun TVE in universities (Kolbe, Partridge \& O'Reilly, 2011). Labelling can affect students' performance. As a result the number of students enrolling for TVE is lower as compared with other faculties in universities. According to Rojewski and Park (2005), the critical cause of decreasing student enrolment in university in TVE programmes is the strong negative stigma that is placed on vocational education, for instance, most families and children regard it as second best, as inferior to the academic route. Universities offering TVE are actively perceived as dead-ends for the minority of students, who unwillingly enter the university because of difficulty with a possibly more "rigorous" academic curriculum (Rojewski \& Park, 2005). To many, vocational institutions are understood as institutions of terminal education for students who fail in general academic school (Rojewski \& Park 2005). Those who have taken courses of study generally called "academic" reap substantial financial returns from their education, thus producing the paradoxical conclusion that academic education has a greater value than vocational education (Kanyongo, 2005). This attitude further impresses the students that academic courses are more "important" or "worthy" compared with vocational courses in terms of job aspirations. This distinction, which is actually grounded in the nature of the two curricula, is allowed to carry the implication that some education prepares students for the 'world of work' and some does not. The traditional distinction was developed by educators, but the labour market has its own way of appraising qualifications (Rojewski \& Park (2005).

Rogan and Grayson (2003) state that students' attitudes to learning and responses to change, are likely to be a major determinant of the student's success in their courses. Additionally, some students with an unrealistic view of themselves may perform poorly too. For instance, those who tend to be overconfident about the requirements of their academics may register very poor performance. Conversely, when students do not believe in themselves or when they have low self-confidence, there are high chances that they will under achieve (Powers, 2006). At times, students imagine that they are victims of the system and this can lead to academic failure. As a result this attitude will lead to students attaining poor results since they would have failed to get help from the lecturers. Also, some students find it difficult to grow or develop because they tend to resist change in their learning process and this impedes their academic progress. In other situations, a student may not work well in groups yet this is a necessary part of the vocational academic environment.

Lauglo, Akyeampong, Mwiria, and Weeks (2004) assert that positive attitudes towards TVE should be promoted among students if they are to acquire skills relevant for future trades and occupations. Plax, Kearney, and Downs (2008) share the same view with Lauglo et al., (2004) when they postulate that promoting favourable attitudes towards a given university subject is the equivalent of encouraging the student to study the subject with eagerness and persistence. There is therefore a dire need for all stakeholders in Zimbabwe to inculcate positive attitudes towards TVE among their children. 
Parents, lecturers and students evaluate the curriculum in relation to what has been done in the past (Gumbo, 2006). The preference for academic achievement by most post-colonial countries is a direct result of the attitudes developed during the colonial era where vocational education was looked down upon (Lauglo et al., 2004; Zvobgo, 1994). However, the researcher feels that improved lecturer attitude and favourable employment outcomes increase student demand for the courses and improve motivation in learning TVE.

Students are almost totally ignorant of the concept of vocational education and of its potential significance for national development. This is not only because of the weakness or even absence of existing vocational guidance, particularly in the primary and junior secondary years but also because of the low status and irrelevant curriculum of vocational education courses which do exist. So they are not ignorant of the realities, but are ignorant of the potential (Rojewski \& Park 2005). From these revelations cited above, the study sought to examine how perceptions of lecturers and students impact on the delivery of the CT curriculum in Zimbabwean universities.

\section{Research Methodology}

\subsection{Research Paradigm}

Post-positivism paradigm facilitated the use of multiple methods and different world views as well as the use of different forms of data collection and analysis, which were key to this study.

\subsection{Research Design}

Concurrent triangulation design was used in this study. This design enhanced the researcher's understanding of the phenomena she was able to look at it from various positions.

\subsection{Population}

The population of this study comprised university Heads of Departments, lecturers, students and Operations managers of Clothing manufacturing industries.

\subsection{Sample and Sampling Procedures}

The sample consisted of 2 Heads of Departments, 32 lecturers, 24 students for the focus group and 2 Operations managers from the 2 Clothing manufacturing industries who were purposively selected.

\subsection{Data Collection Methods}

Interviews, focus group discussions, questionnaires, observations and document analysis were used to collect data.

\subsection{Research Instruments}

Questionnaires were administered to 16 lecturers. In self-administered group questionnaires, data is gathered in large amounts from many participants concurrently as the researcher waits while a whole group of respondents complete questionnaires (Cohen, Manion and Morrison 2007).

The researcher also made use of interviews. Two Heads of Departments, 16 lecturers and 2 Operations managers were interviewed. The major advantage of interviews was their flexibility and adaptability (Babbie \& Mouton, 2006).

Twenty four students participated in the focus group discussions. Focus group interviews yield a large amount of interaction on the topic in limited time (Babbie \& Mouton 2006).

The use of documents as a data collecting technique enabled the researcher to obtain a lot of data on the perceptions, values and beliefs of participants (Maree, 2007).

Observations were employed. They enabled the researcher to collect data on the physical setting organisation of the universities' laboratories, as well as well as the work rooms in the Clothing manufacturing industries. 


\subsection{Data Analysis}

Qualitative data were analysed alongside quantitative data.

\subsection{Measures to ensure Validity/ Reliability and Trustworthiness}

Validity is an important component of research which tenders the result to be valid or invalid and as such, if the results are invalid, the purpose of research becomes useless. In qualitative studies, an instrument yields trustworthy data to the extent that inferences made on the basis of the data are in fact accurate.

\subsection{Ethical consideration}

Permission to conduct the study in both the universities and industries was sought from the responsible authorities. All participants voluntarily participated in the study. The names of institutions and respondents remained anonymous throughout the study. All respondents were assured the right to privacy and protection from any form of harm.

\section{Results and Discussions}

From the findings it emerged that lecturers' views on the mandate of Clothing and Textiles curriculum ranged from producing competent workers with required skills and to make consumers appreciate locally made clothes and boosting the economy through exporting fabric and clothes. The following were the views from the respondents:

Produce competent employees for the industry. Job creation through skills- acquisition thus producing an individual who is creative and enterprising and self-reliant. (UAL)

It's boosting the economy by exporting locally made fabric and clothes thus bringing foreign currency. (UBL)

As a follow up the respondents were made to respond to whether or not the university was responding to this mandate. Some lecturers were in agreement that the universities were responding to this mandate and some thought the universities were not. Lecturers who were in agreement explained:

Yes, some university students have been absorbed in clothing manufacturing industries because of their competence and some are now entrepreneurs. (UAL)

Giving a totally different view some respondents argued:

No, products from universities are not competent since they lack hands on skills because of lack of resources or machinery. (UAL)

No, universities should link with industries. What is being taught in universities does not align with the expectations of the industries. The universities are behind in terms of machinery. (UBL)

From these responses it was laid bare that some of the respondents were of the view that the universities were responding to the CT mandate since they were producing students who were marketable since some were now employed in the Clothing industries because of the skills they acquired in universities. However, some had a disputing view since according to them; universities were not meeting their mandate for the students they were producing lacked hands on skills because they had no exposure to the machinery and equipment. There was need to improve the link between universities and industries so that what is being taught in universities aligns with the needs of the industries so as to enable the universities to produce a holistic student with the theory and hands on attributes of CT.

Data was also solicited to establish from lecturers through interviews whether they managed to teach every topic in the curriculum that they were expected to teach. There was overwhelming evidence that some lecturers did not teach all the aspects they were expected to teach. Validating this point respondent UAL explained:

I find myself concentrating on those topics I know best because of limited knowledge in some topics. (UAL)

Respondent UBL replicated the same sentiments remarking:

Shortage of resources makes me concentrate on some topics at the expense of others. I cannot concentrate on topics I know will pose challenges when it comes to the practical aspect. (UBL) 
Worse still, this study established from the analysed documents: the syllabuses and the lecturers' schemes and plans of work, that there was a great discrepancy between the topics in the CT course outline, those they included in their schemes and plans of work and those that the lecturers actually covered or taught. Most of the fundamental topics were not covered. In concurrence, data from questionnaires also revealed that all lecturers 16(100\%) did not cover all topics that they were expected to teach. They alluded this scenario to competency issues, as result they explained that they try by all means to concentrate on the topics they are well versed in. Another outstanding finding from this study was that the majority of the lecturers did not cover all the topics they were supposed to cover as per curriculum requirement, but they concentrated on those they found to be interesting. King and Martin (2002) explain the TVE "fallacy" as a challenge between planning and reality. One can deduce that when lecturers fail to deliver curriculum in the manner it is supposed to be done, this impacts negatively on students' performance and future aspirations and also it defeats the whole purpose of planning in education. When educators fail to follow the curriculum which is the roadmap in teaching and learning, there is bound to be some inconsistency in as far as the delivery of the curriculum is concerned.

The cause for concern on such type of teaching was the impact it had on the quality of students the University system would produce. The curriculum taught was so immensely different from the one planned by the universities. The researcher reasons that the end product from the universities would be a raw one considering the fact that most lecturers concentrated only on theory leaving out the practical aspect of the subject as earlier stated and now it has been exposed that the same lectures did not teach the entire topics they are supposed to teach. Furthermore, Verspoor (1989: 133) in Rogan and Grayson (2003) alludes that:

in nearly all instances low education outcomes result from poor implementation of what was essentially a good idea. As a result, a great deal of time, money and effort may be wasted, as good ideas are never translated into classroom reality.

Porter (2006) also argues that the curricula are well designed with aims that are praiseworthy but all too often the attention and energies of policymakers are focused on the 'what' of desired educational change, neglecting the 'how' and this hampers the delivery of the programme.

In response to what helped the respondents teach, the interviews held with lecturers unearthed that $8(100 \%)$ of the lecturers in university A found most topics interesting and as a result, they often spent extra time trying to obtain more information about them. In university B, it was revealed that $3(37.5 \%)$ revealed that the behaviour of students enabled them to deliver the lectures well. However, the other $5(62.5 \%)$ lectures stated that it was their personal approaches or the methods they used that helped them to teach. Findings from quantitative data exposed the same scenario as qualitative data that in universities $A$ and $B, 2(25 \%)$ and $3(37.5 \%)$ lecturers respectively expressed that they found most topics interesting and often spent extra time trying to obtain more information about them and $6(75 \%)$ and $5(62.5 \%)$ from universities $A$ and $B$ respectively stated that it was the behaviour of students which helped them teach. The researcher opines that it is fundamental for students to be self-motivated in their learning (Brown, 2008). Literature reveals that students' academic self-concept is both an important outcome of education and a powerful predictor of student success (Brown, 2008). Belief in one's own abilities is highly relevant to successful learning. Schneider, Gruman, and Coutts (2012) comment that students with a well-developed ability to manage their own learning are able to choose appropriate learning goals, to use their existing knowledge and skills to direct their learning, and to select learning strategies appropriate to the task at hand. However, on the contrary, not all students are intrinsically motivated to learn. There are some who need a push from the lecturer. Powers (2006) concurs that when students are not intrinsically motivated to learn, or when they have low self-confidence, the chances that they will under-perform will be high.

The fact that the majority of lecturers expressed that they found most topics interesting and as a result, they often spent extra time trying to obtain more information about them has a negative impact on the delivery of the CT curriculum. It goes without reason that teaching is not about the topics that are interesting to the lecturer but it is about all the topics the student is supposed to learn. The inverse is also true, that when some aspects of the curriculum are not interesting, the lecturers will not try to find more information about them. As a result the delivery of CT will not meet the required standard. The high participation rate in lectures showed that students had read the topic beforehand as they responded to the lecturer when questions were asked. These findings correlate with what was revealed in the interview discussions with students that it was out of their own initiative to learn that they read on suggested readings beforehand that enabled them learn. This was also witnessed when the researcher observed some CT lectures for the way students participated and contributed in the lectures showed they had done some reading prior to the lectures. This made life easier for the lecturer for the students will be having some idea on what the topic will be all about even though they would not have understood everything they would have read about. 
In response to challenges that kept students from learning the subject better, it was revealed that students were not happy with the way lecturers were marking their work, the way marks were allocated, taking time to give them back their marked work and labelling by other students. Students exclaimed:

It has become a practice that some lectures award marks on the basis of the mark one attained in the first test or assignment. In as much as one will thrive to aim higher, the marks will not change. For example if you get 55, your range of marks will be in the 50s and if you get 70 or 80 , that will be your range. This is unfair to students since no matter how hard you may work; your effort will not be realised or rewarded since the lecturer would have rated you already. (FGUB2)

Lecturers delay in giving us feedback, it may take a month or so before they give us back the work we had submitted for marking. (FGUA2 \& FGUB1)

Of concern to note is that most of the challenges that the students unveiled lay on the ways lecturers were conducting themselves with students in the delivery of CT, thus making them the sources of the challenges. It was also revealed through data elicited from respondents that poor processing of marks was considered a serious concern by students and was thus the most contested issue of all their qualms. There was overwhelming evidence that some lecturers did not give immediate feedback to students when submit their work for marking. This practice has been seen to be a major deterrent to students learning. Marking has to be objective not subjective. It has to show its intention or purpose. From the findings of the study, when lecturers did not award part marks to students' essays, it gave students an element of mistrust and when marks are not allocated to students as they deserved, it became a challenge to the learning situation since it would be biased. The view people have on $\mathrm{CT}$ that its meant for low achievers was also a challenge to students as well as the way they are labelled by fellow students as low achievers.

In the case of students' views on how their perceptions of TVE have changed as a result of their involvement in $\mathrm{CT}$, students responded:
When I joined the university I had a negative perception about TVE but now due to exposure in industries I now know there is life in CT. (FGUB2)
I regret doing CT for other students see CT as a course for low academic achievers because of the low entry points required. (FGUA2 \& FGUB1)

From these responses it was unveiled that students' views had changed in both positive and negative ways. From the data it emerged that before enrolling at the university, some students had limited knowledge on CT. Some students thought CT was about fabrics and sewing only, but after enrolling to study CT at university level, they were made to realise that there was more to it than just fabrics. According to Rogan and Grayson (2003) students are not motivated to learn if they don't realise the importance of a learning programme. However, on the contrary, some students regretted why they chose CT for it was seen as a programme for low academic achievers. Some students even lacked the confidence of whether they would get jobs upon completion of the degree programme considering the hassles they encountered when they were looking for places for work-integrated learning. It is of great importance to note that the way educators communicate their beliefs about a programme in the universities and their attitudes towards it play a part on what the students think about the programme. Similarly, strong evidence has suggested that the ways students think about a programme has a compelling effect on motivation and effort to learn (den Brok, Levy, Rodriguez \& Wubbels, 2002). Findings in this study affirm this for students revealed that before they joined the universities they had negative attitude about CT because of limited knowledge, viewing it as a course only limited to fabrics and sewing. It was after orientation when they realised that there was more to $\mathrm{CT}$ than just fabrics and sewing.

Views of lecturers were also sought on the criteria that were used to select students. Qualitative data revealed that these were mainly direct entry, maturity entry and on gender basis. Respondents explained:

Direct entry- where one needs to have 5 "O" Level passes including English and Mathematics with a C or better. A pass in "A" Level Mathematics, Physics, Chemistry or Biology will be an added advantage. (UAL, UBL, HOD-A \& HOD-B) Mature entry-This based on one's years of experience in the teaching CT and nothing else. (UAL, UBL, HOD-A \& HODB)

Students enter on Gender basis, as per government requirement. (UAL, UBL, HOD-A \& HOD-B)

Of interest to note was that both lecturers and HODs shared the same view. It has been reasoned that this was as a result that the selection of students rested on policy issues that were contained in the university policy document. Document analysis authenticated this for the researcher established that there was a clause on the selection of students in university policy documents. On this aspect, both qualitative and qualitative data also revealed that students entered university through academic qualifications, (direct entry), maturity entry in which ones age and experience are 
prerequisites to enrolment and on gender basis. Entry by gender was perpetuated by the MOHTEST in the late 1990s so as to balance the number of boys and girls who entered university. Entry points for girls were lowered since the MOHTEST had realised that fewer girls were performing to meet the university entry points.

As a follow up on the way students were selected, lecturers also responded to whether or not the selection criterion being used affect the way students perceive CT. Lecturers and HODs shared the same views. They commented:

Low points needed for girls, because of gender policy make students perceive CT as a course for low academic achievers and a course which is not as powerful as other courses. (UAL)

Some students look down upon CT as a result of the entry requirements and they opt for other courses. This results in low enrolment. (UBL)

From the Quantitative data, the following information was obtained from respondents; From university $A$ and $B$, all lecturers $16(100 \%)$ responded Yes, since they felt the selection criteria affected the way students perceive $\mathrm{CT}$. Lecturers from university A pointed out that the cut off points for CT are much lower than those in other faculties, for instance 6 points. Students value a programme based on entry points attached to it, as a result, there were very few students in CT compared to other Faculties in the university. The lecturers from university B commented that students see CT as a women's programme, CT students are looked upon by other students, even members of staff, including the management body since most students who enrol for the course do not have Mathematics which is a prerequisite.

Findings from the study revealed that the selection criterion being used affected the way students perceived CT. It emerged that students did not put much value to $\mathrm{CT}$ because of the low entry points required as compared to other disciplines like Law, Accounting. Some students got enrolled without all entry requirements. As a result students were not keen to study CT. They opted for other programmes, hence the low enrolment in CT. Students were looked down upon due to duration TVE programmes are given in universities, as well as low formal qualifications typically required as compared to other academic disciplines such as Law, Medicine, and Languages (Mumbengegwi, 2008). This perception has been perpetuated by the low entry requirements into TVE programmes.

\section{Conclusions}

The study concluded that both positive and negative attitudes of lecturers and students impact on the delivery of CT. The attitude of lecturers had a bearing on how students perceived CT.

\section{Recommendations}

In light of issues raised in this study, the following recommendations were made;

- Teacher training should include the use of modern machinery and equipment so as to equip lecturers with the skills needed in the delivery of Clothing and Textiles.

- Admission of students for the Clothing and Textiles programme to be based on merit and on oral or written examinations not on gender basis or low entry points requirements.

- Lecturers need to switch from the old traditional teaching methods which are lecturer centred to more modern student learning methods which allow for active learning and increased student participation, such as field trips, online learning as well as research.

\section{References}

Al-Ali, S. (2005). Instructors' key vocational education competencies in Kuwait: the Department of Production Engineering in the College of Technological Studies.

Babbie, E and Mouton, J (2006). The practice of social research, South African Edition: Oxford University Press.

Baker, D. P., Fabrega, R., Galindo, C., \& Mishook, J. (2004). Instructional time and national achievement: Cross-national evidence. Prospects, 34(3), 311-334.

Bullock, D. (2004). Moving from theory to practice: An examination of the factors that preservice teachers encounter as the attempt to gain experience teaching with technology during field placement experiences. Journal of Technology and Teacher Education, 12(2), 211-237.

Cawelti, G. (Ed.). (2004). Handbook of research on improving student achievement (2nd ed.). Arlington.

Cloete, N., Needham, S., Net, H., Papier, J., Shepard, C., \& Stumpf, R. (2009). Responding to the educational needs of post-school youth. Centre for Higher Education Transformation and the Further Education and Training Institute, p40.

Cohen, L.. Manion, L., and Morrison, K., (2007). Research methods in education. Padstow: Cornwal.

Demanet, J., \& Van Houtte, M. (2012). Teachers' attitudes and students' opposition. School misconduct as a reaction to teachers' diminished effort and affect. Teaching and Teacher Education, 28(6), 860-869. 
den Brok, P. J., Levy, J., Rodriguez, R., \& Wubbels, T. (2002). Perceptions of Asian-American and Hispanic-American teachers and their students on teacher interpersonal communication style. Teaching and Teacher Education, 18(4), 447-467.

First Results from TALIS, OECD 2009).

Flores, M. A., \& Day, C. (2006). Contexts which shape and reshape new teachers' identities: A multi-perspective study. Teaching and teacher education, 22(2), 219-232.

Gumbo, S.D. (2006) Vocationalising Curriculum in Zimbabwe: An Evaluation Perspective Paper presented at the vocationalising Education Conference,London.

Gwaradzimba, E \& Shumba, A (2010). The nature, extent and impact of the brain drain in Zimbabwe and South Africa. Acta Academica, 42(1), 209-241.

Hallinan, M. T. (2008). Teacher influences on students' attachment to school. Sociology of Education, 81(3), 271-283.

Hoy, A. W. (2003). Self-efficacy in college teaching. Essays on Teaching Excellence, 15(7).J Pers Eval Educ (2007) 20:165-184 181

Johanson, K. R. \& Adams, V. A. (2004).Skills development in Sub-Saharan Africa. Washington, DC: World Bank.

Kanyongo, G.Y. (2005). Zimbabwe's Public Education Systems Reforms: Successes and Challenges. Shannon Research Press. Washington.

Kersaint, G., Horton, B., Stohl, H., \& Garofalo, J. (2003). Technology beliefs and practices of mathematics education faculty. Journal of Technology and Teacher Education, 11(4), 549-577.

King, K. and Martin, C. (2002) The Vocational School Fallacy Revisited: Education, Aspiration and Work in Ghana 1959-2000'. In International Journal of Education Development 22, pp. 5-26.

Ladd, G. W., Herald-Brown, S. L., \& Kochel, K. P. (2009). Peers and motivation. Handbook of motivation at school, 323-348.

Lauglo, J., Akyeampong, A. K., Mwiria, K., \& Weeks, S. (2004). Vocationalised secondary education revisited. In CIES National Conference.

Makochekanwa, A., \& Kwaramba, M. (2010). Dwindling access to basic services in Zimbabwe.

Maree,K, (2007) First Steps In Research. Van Schaik Publishers, Pretoria, South Africa.

Mumbengegwi, S.C, (2008). Zimbabwe Quality Education For All: Knowledge, Technology and the future of Higher Education. International ICE.

Oketch, M. O. (2007). To vocationalise or not to vocationalise? Perspectives on current trends and issues in technical and vocational education and training (TVET) in Africa. International Journal of Educational Development, 27(2), 220-234.

Plax, T. G., Kearney, P., \& Downs, T. M. (2008).Communicating control in the classroom and satisfaction with teaching and students.Communication Education, 35(4), 379-388.

Porter, (2006), Porter, M. E (2006). The link between competitive advantage and corporate social responsibility. Harvard business review, 84(12), 78-92.

Powers, T ;Koestner, R., Horberg, E. J., Gaudreau, P., Di Dio, P., Bryan, C., \& Salter, N. (2006). Bolstering implementation plans for the long haul: The benefits of simultaneously boosting self-concordance or self-efficacy. Personality and Social Psychology Bulletin, 32(11), 1547-1558.

Rex, J \& Singh, G. (2003). "Pluralism and Multiculturalism" in Colonial and Post Colonial Society, Thematic. Introduction International Journal on Multicultural Societies (IJMS),5(2),106ISSN18174574,www.unesco.org/shs/ijms/vol5/issue2/art1@UNESCO

Rogan, J. M., \& Grayson, D. J. (2003). Towards a theory of curriculum implementation with particular reference to science education in developing countries. International Journal of Science Education, 25(10), 1171-1204.

Rojewski, J.W., \& J.H. Park. (2005). Secondary vocational education in South Korea: Addressing challenges and seeking solutions. International Journal of Vocational Education and Training 13, no. 2: 7-29.

Schneider, F. W., Coutts, L. M., \& Gruman, J. A. (2012). Applied social psychology: Understanding and addressing social and practical problems. (2nd ed.). Thousand Oaks, CA: Sage Publications, Inc.

Schofield, J. W. (2006). Migration background, minority-group membership and academic achievement research evidence from social, educational, and developmental psychology.

Skinner, E. A., \& Belmont, M. J. (1993). Motivation in the classroom: Reciprocal effects of teacher behavior and student engagement across the school year. Journal of educational psychology, 85(4), 571.

Smerdon, B. A. (2002). Students' perceptions of membership in their high schools. Sociology of Education, 75, 287-305

Thornton, B., Peltier, G., \& Hill, G. (2005). Do future teachers choose wisely: a study of pre-service teachers' personality preference profiles. College Student Journal, 39(3).

Van Houtte, M., \& Stevens, P. A. (2008). Sense of futility the missing link between track position and self-reported school misconduct. Youth \& Society, 40(2), 245-264.

Van Houtte, M., \& Van Maele, D. (2012). Students' sense of belonging in technical/ vocational schools versus academic schools: the mediating role of faculty trust in students. Teachers College Record, 114, 7.

Van Houtte, M. (2006a). School type and academic culture: Quantitative evidence for the differentiation-polarisation theory. Journal of Curriculum Studies, 38, 273-292.

Van Houtte, M. (2006b). Tracking and teacher satisfaction: The role of study culture and trust. Journal of Educational Research, 99, 247-254.

Woodrow, J. E. (2002). The Influence of Programming Training on the Computer Literacy and Attitudes of Preservice Teachers.Journal of research on Computing in Education, 25(2), 200-19.

Zvobgo, R.J. (1994). Colonialism and Education in Zimbabwe. Harare: Space Books 